\title{
Quality of tomatoes under different transportation conditions by principal component analysis ${ }^{1}$
}

\author{
Túlio de Almeida Machado ${ }^{2 *}\left(\mathbb{D}\right.$, Anderson Gomide Costa ${ }^{3}$, Rhayf Eduardo Rodrigues ${ }^{2}$, \\ Murilo Alberto dos Santos ${ }^{2}$, Ana Carolina de Lima Ribeiro ${ }^{2}$, Clarice Aparecida Megguer ${ }^{2}$
}

\author{
$10.1590 / 0034-737 X 202067060004$
}

\begin{abstract}
Bulk transportation of tomatoes is a step with high occurrence of mechanical impacts, leading to increased losses and reduction in the quality of fruits arriving at the industry and reaching the consumer market. The present study aimed to evaluate variations in physical-chemical parameters associated with the quality of tomato fruits, occurred during bulk transportation, using an approach based on principal component analysis. The experiment was conducted in the municipality of Morrinhos - Goiás, Brazil. Firmness, titratable acidity, total soluble solids, $\mathrm{pH}$ and mass loss were evaluated in the fruits at three times: during transportation on dirt road; after transportation on dirt road and during transportation on asphalt-paved road; after transportation on dirt and asphalt-paved roads and arrival at the processing yard. Principal component analysis was used to identify which physical-chemical attributes were most affected by transportation and generate quality indices of tomato fruits according to the physical-chemical attributes. Variation in the attributes was explained by the first three principal components, which had cumulative explained variance of $78.37 \%$. Titratable acidity, soluble solids and mass loss had the highest correlations with the most representative principal component, thus being the most affected attributes during the bulk transportation of the fruits.
\end{abstract}

Keywords: Solanum lycopersicum L.; bulk cargo; mechanical damage.

\section{INTRODUCTION}

Tomato agro-industry needs a special type of fruits produced by low-growing plants, without sophisticated cultivation practices, and reduced cost of production. Harvested fruits must have high resistance to bulk transportation, predominant and uniform color of physiological maturity, and high contents of soluble solids and citric acid (Ferreira et al., 2017).

After harvest, fruits are highly susceptible to mechanical damage during post-harvest, packing and transportation. Serious damage due to mechanical impacts generates changes in the quality of attributes (Li et al., 2017) and leaves the fruit more susceptible to loss (fruits disintegrate) during the processing steps in the industry.
Studies allowing the evaluation of the quality of agricultural products during post-harvest are extremely important as they are requisites for waste reduction, increasing profits and competitivity (Ribeiro et al., 2014; Oliveira et al., 2015). Attributes associated with fruit quality such as mass, volume, firmness, soluble solids and titratable acidity are important parameters that influence decision-making during the phases of harvest, post-harvest and marketing ( $\mathrm{Rab}$ et al., 2013; Tabatabaekoloor, 2013).

During transportation, the occurrence of mechanical impacts due to vibrations caused by the movement of cargo trucks on the road is one of the main factors causing damage to vegetables, reducing the overall quality and final economic value of the product. Bani et al. (2006)

\footnotetext{
Submitted on January $25^{\text {th }}, 2020$ and accepted on August $21^{\text {th }}, 2020$.

${ }^{1}$ This work is part of the Doctoral Thesis of the first author.

${ }^{2}$ Instituto Federal Goiano, Campus Morrinhos, Morrinhos, Goiás, Brazil. machado.tulio@gmail.com, rhayf.rodrigues@gmail.com, muriloalberto_13@hotmail.com, lina_franca_carol@hotmail.com, megguer.clarice@gmail.com

3niversidade Federal Rural do Rio de Janeiro, Instituto de Tecnologia, Seropédica, Rio de Janeiro, Brazil. andersongc7@gmail.com

*Corresponding author: machado.tulio@gmail.com
} 
demonstrate that losses of tomatoes due to mechanical impacts during transportation may reach $20 \%$ of the total transported. Evaluating the condition of physical-chemical properties during transportation allows control of quality standards and reduction of product losses (Sirisomboon et al., 2007).

Principal component analysis (PCA) is a multivariate statistical method which has been used to analyze fruit quality, as this technique allows evaluating the influence of the variables simultaneously, determining which parameters are truly representative and generating quality indices.

PCA was used by Bello et al. (2020) to distinguish different maturation stages using colorimetric indices and physico-chemical attributes of tomatoes. Breksa III et al. (2015) also demonstrated the potential of PCA to distinguish tomato cultivars based on morphological characteristics and quality attributes.

The present study aimed to evaluate the variations in physical-chemical attributes associated with the quality of tomato fruits, occurred during bulk transportation, using an approach based on principal component analysis.

\section{MATERIAL AND METHODS}

The experiment was conducted at Bom Jardim Farm, located in the municipality of Morrinhos-GO, Brazil. The mean altitude of the property is $773 \mathrm{~m}$, at latitude and longitude of $17^{\circ} 63^{\prime} 39.9^{\prime \prime} \mathrm{S}$ and $49^{\circ} 07^{\prime} 36.8^{\prime \prime} \mathrm{W}$, respectively. The experimental area was limited to 55 ha under center pivot irrigation. At harvest, the soil had mean water content of 18\% (Embrapa, 2017), considered as suitable for machinery traffic in the area. The predominant soil is Dark Red Latosol (Embrapa, 2018).

In the study area, the tomato hybrid BA5630 from BHN was transplanted and grown under no-tillage system and the cultivation practices were carried out as recommended for commercial cultivation.

Mechanical harvest was carried out at 127 days after transplanting, using a self-propelled harvester manufactured by GUARESI, G-89/93 MS 40" model, with 128.7-kW FIATIveco engine, with suspended harvesting platform equipped with electronic sorter of green fruits and clods.

The sorting system of the evaluated harvester was set according to the configuration suggested by the manufacturer, which consisted of $12 \mathrm{rpm}$ rotation and 2.5 $\mathrm{Hz}$ vibration frequency. The sensor to separate clods and green fruits was turned off during the operation, and green fruits and impurities were manually sorted by five workers directly on the harvester's conveyor belt. In the commercialization of the production of agro-industrial tomatoes there is a tolerance in the purchase of immature fruits by the industry, being a common practice the operation of harvesters with the separation sensor turned off.
Tomatoes were transported to the industry using a Volkswagen truck, 31330 model, with $242.7 \mathrm{~kW}$ Cummins ISL engine and $6 \times 4$ traction and coupling for dump buckets ( $40 \mathrm{~m}^{3}$ capacity).

In this step, the tomatoes used for analysis of physicalchemical attributes were collected were collected from the dump bucket at an intermediate depth (between 0.40$1.20 \mathrm{~m})$. The collection of fruits inside the bucket was performed using the sampler and the methodology described by Machado et al. (2018). Twenty-four fruits were collected at three different times during the transportation: during transportation on dirt road (T1); after transportation on dirt road and during transportation on asphalt-paved road (T1+T2); after transportation on dirt and asphalt-paved roads and arrival at the processing yard $(\mathrm{T} 1+\mathrm{T} 2+\mathrm{T} 3)$. The mean displacement speeds of the truck were $22 \mathrm{~km} \mathrm{~h}^{-1}$ on 10 min courses for dirt road and 63 $\mathrm{km} \mathrm{h}^{-1}$ on 30-min courses for asphalt-paved road. The asphalt pavement was classified as regular (DNIT, 2005).

Then, all collected fruits were taken to the laboratory and analyzed for the physical-chemical attributes firmness, titratable acidity, total soluble solids (TSS), pH and mass loss. Harvesters regulations and operations management remained uniform during the harvest, ensuring that the variability present in the fruit quality attributes were not influenced by the machine.

Firmness was determined by the external force method (Calbo \& Nery, 1995), in which five fruits were analyzed per replicate with two measurements per fruit. Titratable acidity was determined by the official methodology, described by AOAC (2010).

TSS was determined using an Instrutemp brand portable refractometer with scale of $0-32{ }^{\circ}$ Brix. Levels of $\mathrm{pH}$ were determined using a Lucadema $\mathrm{pH}$ meter, Luca 210P model.

For mass loss determination, the fruits were left on a natural yard for drying and weighed at 0, 24, 48, 72, 96 and $120 \mathrm{~h}$ after harvest. Mass loss was estimated relative to the initial mass of the fruits before treatment and after the last weighing, and its values were transformed to percentage of mass loss.

\section{Data analysis}

For exploratory analysis, the variation of each physical-chemical attribute at the 3 times established (T1; $\mathrm{T} 1+\mathrm{T} 2 ; \mathrm{T} 1+\mathrm{T} 2+\mathrm{T} 3$ ) were evaluated through boxplot diagrams.

Lilliefors test was used to analyze the normal distribution of data for each physical-chemical attribute. Posteriorly, the correlation between physical-chemical attributes was evaluated based on the significance obtained by the Pearson's correlation matrix at $p>0.01$ and $p>0.05$ probability levels by t-test. 
For multivariate analysis through principal component analysis (PCA), firstly the values of the physical-chemical attributes were normalized in order to standardize the variables as mean 0 and variance 1, according to Equation 1. This normalization was necessary to remove the dimensional effect of the units from the physical-chemical attributes.

$Z_{i j}=\frac{x_{i j}-\bar{x}_{j}}{S\left(x_{j}\right)}$

Where, $x_{i j}$ is the original value of each data referring to each physical-chemical attribute; $\bar{x}_{j}$ is the mean for each physical-chemical attribute $\mathrm{j} ; S(x j)$ is the standard deviation for each physical-chemical attribute $\mathrm{j}$.

Covariance matrix of normalized physical-chemical attributes was used in Equation 2 to obtain the roots (eigenvalues), which corresponded to the variance of each principal component.

$\operatorname{det}[C-\lambda I]=0$

Where, $C$ is the covariance matrix of the normalized physical-chemical attributes of size $5 \times 5 ; \lambda$ are the values of the 5 roots resulting from the eigenvalue equation of the covariance matrix; $I$ is the identity matrix of size $5 \times 5$.

For each eigenvalue, an eigenvector of size 5 was obtained, and the values of the eigenvectors corresponded to the coefficients of each principal component $\mathrm{CP}_{\mathrm{i}}$ (Equation 3).

$C P_{i}=a_{i 1} X_{1}+a_{i 2} X_{2}+a_{i 3} X_{2}+a_{i 3} X 2+a_{i 4} X_{2}+a_{i 5} X_{5}$

Where, $\mathrm{a}_{\mathrm{ij}}$ are the eigenvectors associated with each physical-chemical attribute Xp.

The proportion of the variance explained by each principal component $\mathrm{PVE}_{\mathrm{i}}$ (contribution of each component) was obtained using Equation 4. From this information it was possible to determine how many principal components were necessary to explain the variance observed in fruit quality attributes during the transportation on the three types of pavement. This number of principal components was obtained when the cumulative percentage of the explained proportion reached value higher than $70 \%$.

$P V E_{i}=\frac{\lambda_{i}}{\operatorname{trace}(C)} 100$

The degree of influence of each physical-chemical attribute $\mathrm{X}_{\mathrm{j}}$ exerted on each principal component $\mathrm{Y}_{\mathrm{j}}$ was evaluated using the correlation coefficient (Equation 5), and the importance of each physical-chemical attribute of each principal component was compared by calculating the loading of each variable (Equation 6).
$\operatorname{Corr}\left(X_{i} Y_{j}\right)=r_{X j} Y_{j}=a_{1 j} \frac{\sqrt{\hat{\operatorname{Var}}\left(Y_{j}\right)}}{\sqrt{\hat{\operatorname{Var}}\left(X_{j}\right)}}$
$W_{p}=\frac{a_{1 p}}{\sqrt{\hat{\operatorname{Var}}\left(X_{p}\right)}}$, with $p$ ranging from 1 to 5

Thus, the equations of the principal components resulting from linear combinations of physical-chemical attributes were used as indexes to evaluate the quality of tomatoes during fruit transport.

\section{RESULTS AND DISCUSSION}

The variation in the physical-chemical attributes during transportation indicated responses between similar ranges for the three times evaluated (Figure 1). Highest amplitudes between maximum and minimum values were observed during the transportation on dirt road (T1) for all attributes analyzed, which may indicate that alterations in fruit physical-chemical characteristics occur mainly due to the transportation on this type of surface.

In this context, Almeida (2005) reports that vibrations occurring in the fruit-carrying vehicles result in vibrations with frequency from 2 to $20 \mathrm{~Hz}$, causing increased tension and rupture of the membrane of agricultural products.

Freire Júnior \& Soares (2014) pointed out that the lack of protection in the trucks to minimize vibration transmission and poorly paved roads are factors that directly influence qualitative losses in the transportation of agricultural products in the different steps of the fruitvegetable chain. The fact that the transportation was carried out in a compartment with protection may have reduced the quantity of injuries on tomato fruits. Thus, the hypothesis that the damage observed on tomato fruits was essentially caused by the transportation on dirt road, where there is no pavement, is corroborated.

Another moment subject to high incidence of losses is after the step of resting, at the end of the processing and at the marketing center (Bassan et al., 2015), due to handling and displacement of the fruits, which consequently leads to high incidence of mechanical impacts. However, in this experiment, when tomato fruits were evaluated at the processing yard no increase was detected in the alterations of their physical-chemical characteristics, which indicates that this step did not influence the quantity of injuries observed.

Based on the significance of physical-chemical attributes during the transportation of the fruits (Table 1), firmness and $\mathrm{pH}$ were significantly correlated at 0.01 level. Acidity was significantly correlated with soluble solids and mass loss at 0.01 level, as well as TSS and mass loss, which allows concluding that these attributes are simultaneously affected by parameters associated with the transportation, such as vibration and cargo weight. 
Significant normality ( $\mathrm{p}$-value $<0.05$ ) according to the Lilliefors normality test was detected for the physicalchemical attributes, with the exception of firmness, fact that may explain the significant non-correlation with most other attributes.

The maturation at harvest time is a factor affecting the $\mathrm{pH}$ of the fruit. In this experiment, there was no variation in the harvest season, which allowed the $\mathrm{pH}$ to remain in a stable range, regardless of the treatments, resulting in the non-correlation with most of the physical-chemical attributes. In addition, the analyzes were carried out immediately after transportation, making it impossible to modify attributes that could influence the $\mathrm{pH}$, such as ethylene production (Park et al., 2016).

However, mechanical injuries often compromise the barriers which prevent water loss, because they may damage the surface layer of the epidermis, reducing its capacity to resist to water loss ( $\mathrm{Li} \&$ Thomas, 2014; Opara
\& Pathare, 2014), directly influencing the physical and chemical characteristics of the fruits. Thus, fruit mass loss presents itself as a parameter highly influenced by the occurrence of mechanical impacts during transportation. Significant correlation between mass loss and the attributes titratable acidity and TSS corroborates the influence of mechanical impacts on the quality of transported fruits.

In addition to the loss of mass, the firmness of the fruit pulp is another physical parameter that can be influenced by mechanical injuries. During bulk transport, mechanical impacts can result in the rupture of the cell walls of the fruits and consequent loss of water, which reduces the mass of the fruit. This relationship between firmness and mass loss was demonstrated by Machado et al. (2018) who obtained a linear correlation of 0.793 between these parameters due to mechanical impacts during mechanized harvesting of tomatoes.
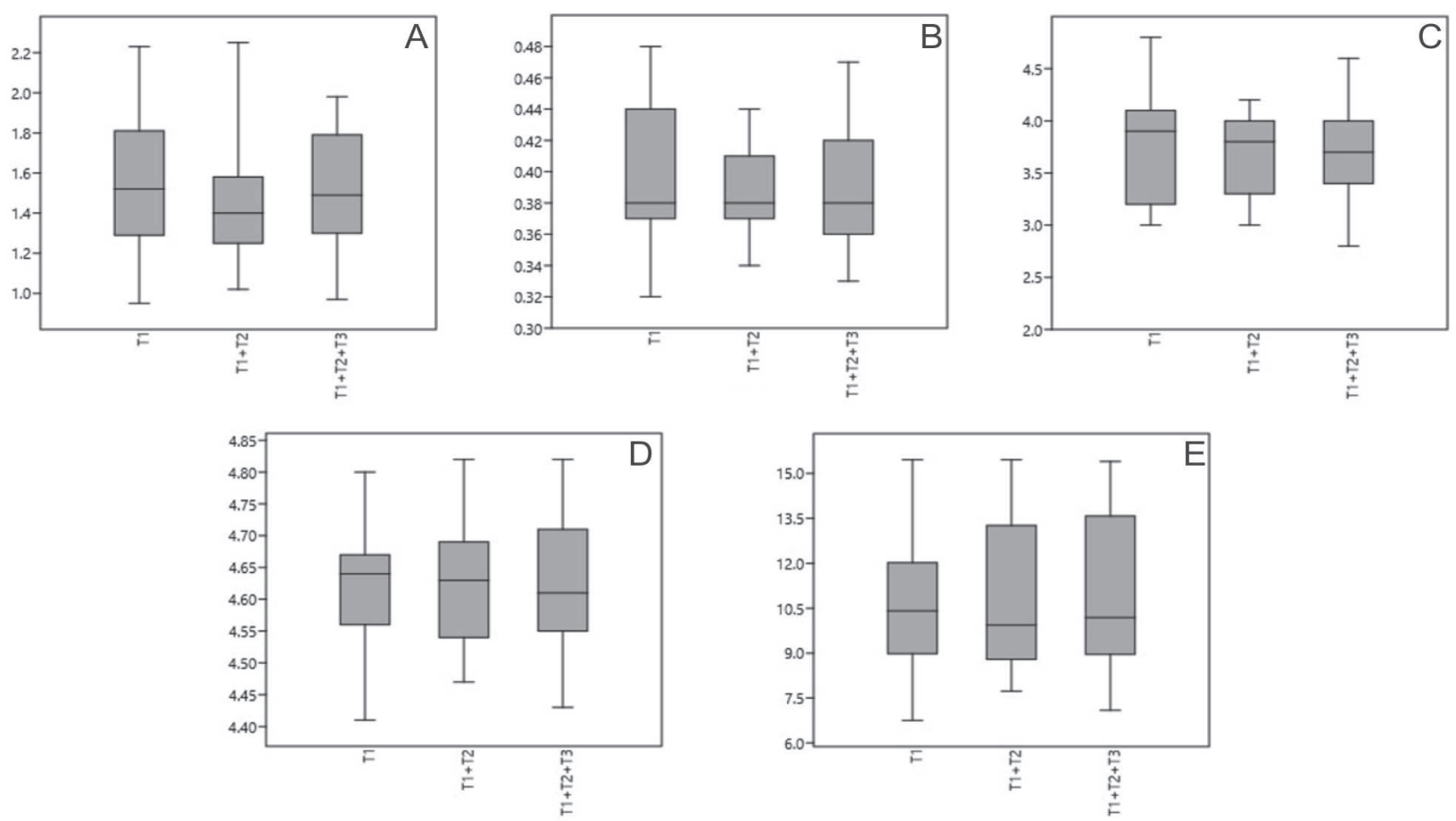

Figure 1: Variations in the measurements of physical-chemical attributes of tomato fruits: (a) Firmness $\left(\mathrm{N} \mathrm{cm}^{-2}\right)$; (b) Titratable acidity (\% of citric acid); (c) Total soluble solids ( $\left.{ }^{\circ} \mathrm{Brix}\right)$; (d) $\mathrm{pH}$; (e) mass (\%), obtained during transportation on dirt road (T1); after transportation on dirt road and during transportation on asphalt-paved road $(\mathrm{T} 1+\mathrm{T} 2)$; after transportation on dirt and asphalt-paved roads and arrival at the processing yard $(\mathrm{T} 1+\mathrm{T} 2+\mathrm{T} 3)$.

Table 1: Significance matrix of Pearson's correlations of the physical-chemical attributes obtained during the transportation (Ns - not significant; * - significant at 0.05 probability level by t-test; ** - significant at 0.01 probability level by t-test)

\begin{tabular}{|c|c|c|c|c|c|}
\hline & $\begin{array}{l}\text { Firmness } \\
\left(\mathrm{N} \mathrm{cm}^{-2}\right)\end{array}$ & $\begin{array}{l}\text { Titratable acidity } \\
\text { (\% of citric acid) }\end{array}$ & $\begin{array}{c}\text { TSS } \\
\left({ }^{\circ} \text { Brix }\right)\end{array}$ & pH & $\begin{array}{c}\text { Mass loss } \\
(\%)\end{array}$ \\
\hline Firmness & - & Ns & Ns & $*$ & Ns \\
\hline Titratable acidity & - & - & $* *$ & $\mathrm{Ns}$ & $* *$ \\
\hline TSS & - & - & - & $\mathrm{Ns}$ & $* *$ \\
\hline $\mathrm{pH}$ & - & - & - & - & $\mathrm{Ns}$ \\
\hline Mass loss & - & - & - & - & - \\
\hline
\end{tabular}


When PCA was applied, it was possible to observe that the variance in tomato physical-chemical characteristics at the analyzed times can be explained using three principal components (PC), because these PCs showed a cumulative explained variance higher than $70 \%$ (Table 2). The results also indicate that, although PC1 has highest concentration of the variance of the attributes (36.65\%), PC2 and PC3 also had considerable participation in explaining the response of variance of the attributes, indicating that a quality index for tomato fruits as a function of transportation must be presented using the three components.

By analyzing the correlation between the principal components and physical-chemical parameters of tomato fruits (Table 3), it can be noted that mass loss, TSS and titratable acidity are associated with $\mathrm{PC} 1$, and the first two attributes have direct correlation (higher values of the attribute result in higher values of PC1), whereas titratable acidity has an inverse correlation (higher values of the attribute result in lower values of PC1). The attribute $\mathrm{pH}$ had higher association with PC2, while firmness was associated with PC3, and higher values of these attributes result in higher values of $\mathrm{PC} 2$ and $\mathrm{PC} 3$, respectively.

The loadings for each component related to each physical-chemical attribute of tomato fruits were used as coefficients to develop the three quality indices (Table 4), which can be used to evaluate which physical-chemical attributes were affected by transportation of the fruits.
The TQOI_1 index indicates that positive values will be associated with the variation of soluble solids and mass loss due to transportation of the fruits, whereas negative values will be associated with the variation of the attribute titratable acidity. The TQOI_2 and TQOI_3 indices indicate that the higher the positive values, the greater the variation of $\mathrm{pH}$ and firmness, respectively. Values close to zero in these indices indicate low variation of the two attributes during the transportation of tomato fruits.

PCA has been explored by several authors to evaluate attributes linked to the quality of fruits, including tomatoes. Azodanlou et al. (2003) also used PCA to investigate tomato quality based on its sensory characteristics, and sweetness and aroma were the attributes of highest relevance for the analysis of quality. Indirect parameters obtained by electronic sensors (Cheng et al., 2017) have also been tested for automated evaluation of the quality of industrial tomatoes.

Since titratable acidity, total soluble solids and mass loss were the physical-chemical characteristics that most influenced tomato quality, a direct or indirect monitoring of these variables associated with the quality indices obtained in this experiment may help in the control of quality of tomato fruits during transportation. However, due to the explanatory power of the quality index associated with TQOI_1 (36.65\%), it is recommended to complement the evaluation using the $\mathrm{pH}$ and firmness, applied in the quality indexes TQOI_2 and TQOI_3, respectively.

Table 2: Explained variance for the parameters firmness, titratable acidity, TSS, pH and mass loss during the transportation of tomatoes, using principal components (PC)

\begin{tabular}{lccc}
\hline Principal components & Variance & $\begin{array}{c}\text { Percentage of explained } \\
\text { variance }(\%)\end{array}$ & $\begin{array}{c}\text { Cumulative percentage } \\
\text { of explained variance }(\%)\end{array}$ \\
\hline PC1 & 1.83 & 36.65 & 36.65 \\
PC2 & 1.14 & 22.71 & 59.36 \\
PC3 & 0.95 & 19.01 & 78.37 \\
PC4 & 0.63 & 12.63 & 91.00 \\
PC5 & 0.45 & 9.00 & 100.00 \\
\hline
\end{tabular}

Table 3: Correlation between principal components (PC) and physical-chemical parameters of tomato fruits during transportation

\begin{tabular}{lccrrr}
\hline Principal components & Firmness & Titratable acidity & TSS & pH & Mass loss \\
\hline PC1 & -0.39 & -0.60 & 0.78 & -0.07 & 0.84 \\
PC2 & 0.42 & -0.54 & 0.06 & 0.80 & -0.17 \\
PC3 & -0.23 & 0.06 & -0.54 & 0.09 \\
PC4 & 0.77 & 0.50 & 0.54 & 0.17 & -0.02 \\
PC5 & 0.24 & 0.20 & -0.30 & 0.19 & 0.51 \\
\hline
\end{tabular}

Table 4: Tomato quality overall index (TQOI) generated from PC1, PC2 and PC3 associated with physical-chemical parameters of tomato fruits during transportation

TQOI_1 $=-0.45 *($ Titratable acidity $)+0.58 *($ TSS $)+0.62 *($ Mass loss $)$

TQOI_2 $=0.75 *(\mathrm{pH})$

TQOI_3 $=0.79 *$ (Firmness) 


\section{CONCLUSIONS}

The physical-chemical attributes showed greater variations during transport on earth pavement, indicating that changes in fruit quality occur mainly due to transport on this type of pavement.

Considering the input attributes firmness, titratable acidity, total soluble solids, $\mathrm{pH}$ and mass loss, the variation in the quality of tomato fruits from the harvesting area to the processing yard could be explained by the first three principal components (cumulative explained variance of $78.37 \%$ ) resulting from the multivariate analysis.

Titratable acidity, total soluble solids and mass loss had higher correlation with the first principal component (explained variance percentage of $36.65 \%$ ), thus being the most influential parameters for determination of quality indices of tomato fruits during transportation.

\section{REFERENCES}

Almeida D (2005) Manuseamento de Produtos Hortofrutículas. Porto, SPI. 112p.

AOAC - Association of Official Analytical Chemists (2010) Official Methods of Analysis. Washington, AOAC. 450p.

Azodanlou R, Darbellay C, Luisier JL, Villettaz JC \& Amadó R (2003) Development of a model for quality assessment of tomatoes and apricots. Food Science and Technology, 36:223233

Bani RJ, Josiah MN \& Kra EY (2006) Postharvest Losses of Tomatoes in Transit. Agricultural Mechanization in Asia, Africa and Latin America, 37:84-86.

Bassan MM, Mourão-Filho FDAA, Alves RF, Bezerra DF, Couto HTZ \& Jacomino AP (2016) Beneficiamento pós-colheita de lima ácida 'Tahiti' afeta sua qualidade e conservação. Ciência Rural, 46:184-190.

Bello TB, Costa AG, Silva TR, Paes JL \& Oliveira MV (2020) Tomato quality based on colorimetric characteristics of digital images. Revista Brasileira de Engenharia Agrícola e Ambiental, 24:567-572.

Breksa III AP, Robertson LD, Labate JA, King BA \& King DE (2015) Physicochemical and morphological analysis of ten tomato varieties identifies quality traits more readily manipulated through breeding and traditional selection methods. Journal of Food Composition and Analysis, 42:16-25.

DNIT - Departamento Nacional de Infra-Estrutura de Transportes (2005) Diretoria de Planejamento e Pesquisa. Coordenação Geral de Estudos e Pesquisa. Instituto de Pesquisas Rodoviárias. Manual de conservação rodoviária. Rio de Janeiro, DENIT. $564 \mathrm{p}$.

Calbo AG \& Nery AA (1995) Medida de firmeza em hortaliças pela técnica de aplanação. Horticultura Brasileira, 13:14-18.

Cheng SM, Wang J, Wang YW \& Wei ZB (2017) Discrimination of different types damage of tomato seedling by electronic nose. ITM Web of conferences, 11:01-19.

Embrapa - Empresa Brasileira de Pesquisa Agropecuária (2017) Manual de métodos de análise de solo. $3^{\mathrm{a}}$ ed. Brasília, Embrapa. 574 p.
Embrapa - Empresa Brasileira de Pesquisa Agropecuária (2018) Sistema Brasileiro de Classificação de Solos. Brasília, Embrapa. $356 \mathrm{p}$.

Ferreira NC, Vendruscolo EP, Seleguini A, Dourado WDS, Benett CGS \& Nascimento ADR (2017) Growth, yield and quality of tomato fruits in narrow cultivation with the use of paclobutrazol. Revista Colombiana de Ciências Hortícolas, 11:72-79.

Freire Júnior M \& Soares AG (2014) Orientações quanto ao manuseio pré e pós-colheita de frutas e hortaliças visando a redução de suas perdas. Rio de Janeiro, Embrapa Agroindústria de Alimentos. $5 \mathrm{p}$.

Li Z, Andrews J \& Wang Y (2017) Mathematical modelling of mechanical damage to tomato fruits. Postharvest Biology and Technology, 126:50-56.

Li Z \& Thomas C (2014) Quantitative evaluation of mechanical damage to fresh fruits. Trends in Food Science \& Technology, $35: 138-150$.

Machado TDA, Fernandes HC, Megguer CA, Santos NT \& Santos FL (2018) Perdas quantitativas e qualitativas dos frutos de tomate durante a colheita mecanizada. Revista Brasileira de Engenharia Agrícola e Ambiental, 22:799-803.

Oliveira GHH, Corrêa PC, Botelho FM \& Oliveira APLR (2015) Mechanical properties of tomatoes subjected to an induced compression during storage. Journal of Texture Studies, 46:293310 .

Opara UL \& Pathare PB (2014) Bruise damage measurement and analysis of fresh horticultural produce: a review. Postharvest Biology and Technology, 91:9-24.

Rab A, Rehman H, Haq I, Sajid M, Nawab K \& Ali K (2013) Harvest stages and pre-cooling influence the quality and storage life of tomato fruit. Journal of Animal and Plant Sciences, 23:1347-1352.

Park CY, Kim YJ \& Shin Y (2016) Effects of an ethylene absorbent and 1-methylcyclopropene on tomato quality and antioxidant contents during storage. Horticulture, Environment and Biotechnology, 57:38-45.

Ribeiro TP, Lima MAC, Souza SO \& Araújo JLP (2014) Perdas pós-colheita em uva de mesa registradas em casas de embalagem e em mercado distribuidor. Revista Caatinga, 27:67-74.

Sirisomboon P, Kitchaiya P, Pholpho T \& Mahuttanyavanitch W (2007) Physical and mechanical properties of Jatropha curcas L. fruits, nuts and kernels. Biosystems Engineering, 97:201207.

Tabatabaekoloor R (2013) Engineering properties and bruise susceptibility of peach fruits (Prunus persica). Agricultural Engineering International, 15:244-252. 